\title{
Influence of three aphid species used as prey on some biological aspects of the predator Eriopis connexa
}

\author{
William Duarte, Helber Arévalo, Ingeborg Zenner de Polanía* \\ Facultad de Ingeniería Agronómica, Universidad de Ciencias Aplicadas y Ambientales U.D.C.A., Bogotá, D.C., Colombia; \\ *Corresponding Author: izenner@udca.edu.co,wduarte@udca.edu.co; harevalo@udca.edu.co
}

Received 25 April 2013; revised 17 May 2013; accepted 24 May 2013

Copyright (C) 2013 William Duarte et al. This is an open access article distributed under the Creative Commons Attribution License, which permits unrestricted use, distribution, and reproduction in any medium, provided the original work is properly cited.

\begin{abstract}
Up to now, the search for an efficient artificial diet to rear the predator Eriopis connexa, native to the Colombian highlands of Cundinamarca and Boyacá has been without success. Therefore, it is necessary to determine which of the available preys supply the best food for its development, survival and fertility. With this purpose, under controlled conditions, three aphid species, accessible within the natural habitat of the predator, were evaluated. The cabbage aphid (Brevicoryne brassicae) does not provide an adequate nutrition for the predator, and apparently, the glucosinolate content of this aphid is transferred and affecting the predator. Based on the demographic parameters such as net reproductive rate, finite reproduction rate, generational time and intrinsic growth rate, for three consecutive generations, it was determined that none of the other two aphid species can be considered either as optimum prey. Macrosiphum euphorbiae, as prey stands out over the alder aphid, Pterocallis sp., supplied as food. The influence that these three prey species had on the growth potential of the larval stages of the predator, under particular ambient conditions, is reported.
\end{abstract}

Keywords: Predator Rearing; Brevycoryne brassicae; Macrosiphum; Pterocallis sp.; The Alder Aphid; Glucosinolates

\section{INTRODUCTION}

The potential use of the coccinellid predator E. connexa (Germar) as a biological control agent against in- sect and mite pests is supported by numerous studies carried out in different regions of South America [1-5]. However, its employment as a control agent in an augmentative manner is limited by the difficulty of counting on a good source of food for $E$. connexa, which provides all the required nutrients to complete its development, allowing to express its maximal reproductive potential.

It is well known that the most appropriate feed for rearing a predatory insect is precisely its prey [6]. A comparison of studies with different insect species potentially useful for biological control programs, comparing diverse artificial diets with the natural preys, has confirmed this knowledge [7-10].

The E. connexa's diet effect in function of two aphid species, in which temperature also was a factor, demonstrated that the consumption behavior and the developmental rate were affected by the different combinations of these factors [11].

Research directed to develop an artificial diet which allows to replace the natural food sources, reduce costs and make the mass rearing process of this coccinellid less complex, has failed [12, authors, unpublished data]. It is necessary to continue with these efforts, however, while positive results are obtained, it is essential to rely on a natural food source for the efficient improvement of the predators rearing process.

The purpose of this research was to evaluate the influence of the employment as prey of individuals of three aphid species on the survival, the development and the reproductive capacity of $E$. connexa.

\section{MATERIALS AND METHODS}

Brevycoryne brassicae L. aphids employed as prey were obtained from Brassica oleracea var. capitata caged plants; the second aphid species, Macrosiphum euphorbiae Thomas was obtained from a natural popula- 
tion which developed on Hibiscus sp. and the third prey species, the alder aphid, Pterocallis sp., was collected from Alnus acuminate plants, at the campus of the University of Applied and Ambient Sciences, Bogotá D.C., (4³'56"57, 7404'51'30) and 2640 masl.

The experiments were carried out in the agricultural biotechnological laboratory, at $25.5^{\circ} \mathrm{C} \pm 2.5^{\circ} \mathrm{C}, 72 \%$ relative humidity, and a photoperiod of 12:12.

Bioassay treatments consisted of $M$. euphorbiae, $B$. brassicae and the alder aphid confined in a $40 \mathrm{~mL}$ plastic vial with snap on lid (Quality Plásticos, Bogotá). A neonate $E$. connexa, larva was supplied with aphids of each species ad libitum. Daily, the food was replaced and the E. connexa mortality and molts registered.

Adults that emerged from pupae the same day were put together in transparent 500-ml plastic cages with perforated lids, filled with leaves of the respective plant host with aphids, in order to facilitate mating and oviposition. Because of the difficulty to distinguish the adult's sex of the predator, since no evident sexual dimorphism exists, it was necessary to perform dissections, once the adults died.

Mortality, instar or developmental stage changes, oviposition initiation, number of eggs per group of adults and emergence dates of each egg batch, as well as the number of larvae emerged were registered daily.

The data of two or three predator's generations allowed to construct vertical life tables, from which the demographic parameters: net reproduction rate $\lambda$, finite reproduction rate Ro, generational time $\mathrm{T}$ and intrinsic growth rate $r_{m}$ for each of the generations feed with each aphid species were calculated. These parameters were compared through the Jacknife method proposed by Maia [13] using the SAS statistical program, which allowed to establish statistical differences within food sources and generations for each of the demographic statistics. In addition, survival curves were constructed and the comportment type for each food source observed [14].

\section{RESULTS AND DISCUSSION}

Developmental time: Initially it was observed that starting with the first larval instar (Table 1), the proportion of individuals reaching the next instar was influenced by the prey species offered as food, finding that only $6 \%$ of the larvae feed on B. brassicae reached pupal- stage, while $43 \%$ and $78 \%$ did when provided by alder aphid and $M$. euphorbiae, respectively. However, attention is drawn to the fact that E. connexa fed with $M$. euphorbiae were those which reached the pupal stage in the highest proportion. It was interesting to note that, although achieving the highest pupal development, only a few of them $(11 \%)$ reached adult stage, decreasing the initial population to $67 \%$. Nevertheless, it was evidenced that for each natural food source individuals were observed to reach the adult stage, although in low proportions.

These unpredictable results using the aphid $B$. brassicae as a good source of food could be explained in relation to the glucosinolates content in cabbage plants on which the aphids were reared. According to Kushad [15] for some varieties the concentrations of sinigrin amounts for $7.8 \mu \mathrm{mol} \mathrm{DW} \cdot \mathrm{g}^{-1}$ and of $0.9 \mathrm{DW} \cdot \mathrm{g}^{-1}$ for glucobrassicin, which could have an effect on the development of the predator, similar to that observed by Francis [16] for the coccinellid Adalia bipunctata fed with the same Brevicoryne sp. reared on Sinapis alba L., a Cruciferae with high content of glucosinates, which did not allow the predator to complete its cycle. Hopkins [17] mentioned that glucosinolates are one of the examples of plant compounds that interfere with insect-plant interactions and also influence higher trophic levels, via reduced host or prey quality, or that specialist herbivores may even use glucosinolates for their defense. As complementary work on the topic, Kanzana [18] indicated that B. brassicae, an obligate feeder on Cruciferae, has developed its own myrosinasecapable of hydrolyzing in a number of glucosenolates, including sinigrin and accumulate the toxin as defense against predators.

On the other hand, it was found that under experimental conditions $M$. euphorbiae was the prey which was more likely to delay the development of the pre-pupa of the predator. This situation perhaps can be explained by the nutritional quality that each prey species could offer to the predatoror by the relationship between the energy balance of predation, observed in other experiments such as those carried out by Gyenge [11]. The authors observed that depending on the number of preys offered of either Acyrthosiphum pisum Harris or Schizaphis graminum (Rordani), anatomic factors such as malformations of $E$. connexa were influenced.

The duration of the predator's life cycle for each food sources over three generations is shown in Table 2. Be-

Table 1. Effect of the aphid species used as prey on the development of Eriopis connexa.

\begin{tabular}{|c|c|c|c|c|c|c|c|}
\hline \multirow{2}{*}{ Diet (prey) } & \multirow{2}{*}{$\begin{array}{c}\text { Preimaginal } \\
\text { longevity }\end{array}$} & \multicolumn{6}{|c|}{ Proportion reached by each instar or stage } \\
\hline & & Instar II & Instar III & Instar IV & Pupa & Adult & $\mathrm{n}$ \\
\hline Brevicoryne brassicae & $31.0 \pm 10.68$ & 0.65 & 0.47 & 0.06 & 0.06 & 0.06 & 17 \\
\hline Macrosiphumeuphorbiae & $39.21 \pm 2.01$ & 0.89 & 0.78 & 0.78 & 0.78 & 0.11 & 17 \\
\hline Pterocallis sp. & $24.6 \pm 13.63$ & 0.79 & 0.50 & 0.43 & 0.43 & 0.43 & 11 \\
\hline
\end{tabular}


Table 2. Developmental time during three generations of Eriopis connexa fed with three natural diets.

\begin{tabular}{|c|c|c|c|c|c|c|c|c|}
\hline Treatment & Egg & Larva 1 & Larva 2 & Larva 3 & Larva 4 & Pupa & Total larva & Adult \\
\hline \multicolumn{9}{|c|}{ Generation cero } \\
\hline \multirow{2}{*}{ Brevicoryne brassicae } & $10 \pm 0$ & $5.23 \pm 3.23 b c$ & $7.63 \pm 2.11 b$ & $10.62 \pm 3.92 \mathrm{ab}$ & $11 \pm 0 \mathrm{a}$ & $13 \pm 0 \mathrm{a}$ & $28 \pm 0$ & $5 \pm 0$ \\
\hline & (10) [21] & $(3-12)[17]$ & $(5-13)[11]$ & $(7-18)[8]$ & (11) [1] & (13) [1] & (28) [1] & (5) [1] \\
\hline \multirow[t]{2}{*}{ Pterocallis sp. } & $7 \pm 0$ & $7.28 \pm 1.38 b c$ & $7.9 \pm 3.56 b$ & $7 \pm 3.31 \mathrm{ab}$ & $10 \pm 2.12 \mathrm{a}$ & $5.6 \pm 1.51 \mathrm{~b}$ & $30 \pm 1$ & $22 \pm 16.92$ \\
\hline & (7) $[21]$ & $(5-9)[14]$ & $(4-16)[11]$ & $(2-10)[7]$ & $(8-13)[5]$ & $(4-7)[5]$ & $(29-31)[5]$ & $(2-48)[6]$ \\
\hline \multirow{2}{*}{$\begin{array}{c}\text { Macrosiphum } \\
\text { euphorbiae }\end{array}$} & $8.95 \pm 1.46$ & $3.77 \pm 1.26 \mathrm{c}$ & $4.93 \pm 0.92 b$ & $5 \pm 2.74 b$ & $12.07 \pm 2.4 \mathrm{a}$ & $4.35 \pm 0.92 b$ & $25.52 \pm 0.82$ & $20.5 \pm 10.6$ \\
\hline & $(7-10)[20]$ & $(3-7)[18]$ & $(2-7)[16]$ & $(2-9)[14]$ & $(8-17)[14]$ & $(3-6)[14]$ & $(21-30)[14]$ & $(13-28)[2]$ \\
\hline \multicolumn{9}{|c|}{ First generation } \\
\hline \multirow{2}{*}{$\begin{array}{c}\text { Macrosiphum } \\
\text { euphorbiae }\end{array}$} & $3.76 \pm 2.51 \mathrm{a}$ & $4.83 \pm 2.25 \mathrm{a}$ & $3.75 \pm 1.42 \mathrm{a}$ & $3.47 \pm 0.81 \mathrm{~b}$ & $6.05 \pm 1.34 b$ & $4.8 \pm 2.36 \mathrm{a}$ & $17.85 \pm 2.40$ & $40.42 \pm 27.59$ \\
\hline & $(2-11)[51]$ & $(2-11)[43]$ & $(2-7)[41]$ & $(2-5)[36]$ & $(2-8)[34]$ & $(2-15)[41]$ & $(13-25)[40]$ & $(2-93)[19]$ \\
\hline \multirow[t]{2}{*}{ Pterocallis sp. } & $4.11 \pm 1.36 \mathrm{a}$ & $5.56 \pm 1.26 \mathrm{a}$ & $4.35 \pm 1.69 \mathrm{a}$ & $5.4 \pm 3.3 \mathrm{a}$ & $8.37 \pm 1.76 \mathrm{a}$ & $5.62 \pm 1.92 \mathrm{a}$ & $22.77 \pm 3.96$ & $35 \pm 22.54$ \\
\hline & $(2-6)[26]$ & $(4-8)[16]$ & $(2-7)[14]$ & $(2-13)[10]$ & $(5-11)[8]$ & $(3-9)[8]$ & $(15-28)[9]$ & $(2-60)[5]$ \\
\hline \multicolumn{9}{|c|}{ Second generation } \\
\hline \multirow{2}{*}{$\begin{array}{c}\text { Macrosiphum } \\
\text { euphorbiae }\end{array}$} & $3.5 \pm 0.94 \mathrm{~b}$ & $5 \pm 1.13 \mathrm{a}$ & $4.26 \pm 1.9 \mathrm{a}$ & $4.36 \pm 1.02 \mathrm{a}$ & $10.3 \pm 1.7 \mathrm{a}$ & $4.5 \pm 1.31 \mathrm{a}$ & $21.4 \pm 5.54$ & - \\
\hline & $(2-5)[20]$ & $(4-7)[15]$ & $(3-8)[15]$ & $(2-5)[11]$ & $(7-13)[10]$ & $(3-7)[12]$ & $(12-26)[5]$ & - \\
\hline \multirow[t]{2}{*}{ Pterocallis sp. } & $6.31 \pm 1.77 \mathrm{a}$ & $5.92 \pm 4.23 \mathrm{a}$ & $5.11 \pm 1.36 \mathrm{a}$ & $5 \pm 1.00 \mathrm{a}$ & $12.5 \pm 4.12 \mathrm{a}$ & $5 \pm 1.41 \mathrm{a}$ & $25.28 \pm 3.63$ & - \\
\hline & $(4-8)[16]$ & $(3-17)[13]$ & $(4-8)$ [9] & $(4-6)[5]$ & $(8-18)[4]$ & $(4-7)[4]$ & $(20-31)[7]$ & - \\
\hline
\end{tabular}

Values of the same column followed by the same letter are not statistically different (Ducan 5\%) for each of the generations.

tween food sources and the initial generation, the egg stage was not analyzed, because eggs were deposited by females fed in a similar way in all treatments. However, no significant differences between treatments, in the egg developmental time of the first generation, were noted. Eggs from females fed alder aphid in the second generation significantly extended the developmental time of eggs.

No significant differences in the duration of each larval instar of the predator fed natural prey were noted. This tendency was maintained during the whole larval stage. Only for the first generation, the third $E$. connexa instar was significantly prolonged when fed on $A$. acuminate, which also extended the total developmental time of the larval stage.

Additionally, the significant increase in the developmental time of the coccinellid pupa occurred when larvae were fed on $B$. brassicae, observing that only one individual reached this stage, showing again the possible influence of glucosinolates that this aphid putatively keeps as a defense against coccinellids [18].

Geynge [11] observed significant variation in the duration of the larval stage of E. connexa fed with two dif- ferent aphid, which had a marked influence on the population growth parameters, determined by the age of the females, their fecundity and survival.

Similar results were obtained by Stathas [19] studying in Greece the already introduced predator to Colombia, Harmonia axyridis (Pallas) (Coleoptera: Coccinellidae), which could turn into a competitor for the native E. connexa. This coccinelid has been observed to feed on Aphis sp. on citrus on the U.D.C.A's campus. The authors fed the predator with Aphis fabae Scopoli and Dysaphis crataegi (Kaltenbach) under controlled laboratory conditions and four constant temperatures, finding that the life cycle duration of $H$. axyridis was shorter when the predator fed on D. crataegi than on A. fabae at high temperature, concluding that the first aphid species might be a better diet for rearing the predator.

However, the effect of temperature on other biological parameters of the predator, such as fecundity, has also to be considered.

Comparing diets for $H$. axyridis, Reznik [20] found that the pre-imaginal development of the predator was much shorter when larvae fed on green peach aphid $(M$. persicae) than on eggs of the Angoumois grain moth $\mathrm{Si}$ - 
totroga cerealella (Olivier) (Lepidoptera: Gelechiidae).

Research carried out by Obrycki and Orr [21] on the effect of Acyrthosiphon pisum Harris, Rhopalosiphum maidis (Fitch) and eggs of Ostrinia nubilais (Lepidoptera: Noctuidae) on the development of three neartic coccinellids showed that the total developmental time of the predators increased when the food was unsuitable. These results may be applicable to E. connexa.

The bioassays conducted with the first generation, which began with eggs laid by field-collected females, we observed a very short duration of the adult stage in all treatments, which can be attributed rather to the experimental conditions than to the effect of the prey species.

Survival and fertility: A different survival rate for each of the food sources was detected (Figure 1). Treatments1, 2 y 3 in which the predator was fed with M. euphorbiae, independent of its generation, presented a survival which adjusts to an idealized curve type I [14], indicating that the predator had a probability near to $100 \%$ to live in a constant way during all stages, and presented a massive death within the adult stage. The massive death of the adults coming from eggs deposited by field-collected females started on day 57, while that of the first laboratory generation on day 59 and for the second generation on day 50 . This survival type is ideal for rearing under laboratory conditions [14], therefore it is considered that the methodology employed might be used as control in future biological research with this predator.

Within treatments 4,5 y 6 where the predator was fed aphids obtained from A. acuminata different survivals rates were observed during the three generations. In generation cero, survival control, the survival adjusts to an idealized curve type II, which means that a constant number of individuals die per time unit. Within the first generation the survival adapts to a compound curve from day cero up to day 26 , which corresponds to the preimaginal stages, survival which adjusts to an idealized

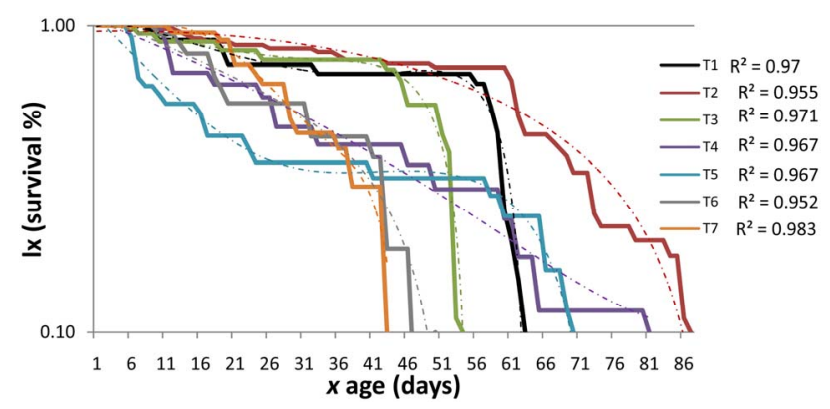

Figure 1. Survival of Eriopis connexa during three generations, fed with three aphid species. Treataments 1,2 y 3 food: Macrosiphumeuphorbiae. Treatments 4, 5 y 6 food: Pterocallis sp. coming from $A$. acuminata. Treatment 7 food: Brevicoryne brassicae. T1, T4 y T7 descendants from field collected adults, T2 y T5 first laboratory generation and T3 yT6 second laboratory generation. curve type III representing the existence of a constant fraction that dies during a time unit. From day 26 on, corresponding to the adult stage, survival adjusts to a curve type I, which is not ideal for rearing under laboratory conditions. For the second generation the survival presented a curve type I, however in this case, the massive death occurred within the adult stage; it is observed before the medium generation time which oscillates between 63 and 70 days, which cannot be considered ideal. Overall the survival presented with in the treatments 4,5 and 6 allow to conclude that the aphid obtained from $A$. acuminata is not an ideal food for rearing E. connexa.

When the predator was fed with $B$. brassicae (treatment 7), the survival adjusts to an idealized curve type I, but in this case the prey cannot be considered an optimum food source, since the massive death occurred previous to the adult development.

The food effect on the survival of E. connexa can be attributed to a low palatability and to the fact that some preys do not contain the necessary nutrients for the normal development of the coccinellid. This could be confirmed under both laboratory and field conditions, where the predator has neither been observed feeding on $B$. brassicae, nor on the aphid from A. acuminata. On the other hand under laboratory conditions a low consumption of the alder aphid was observed, which suggests a low palatability. González [22] isolated from alder plan tradical nods phenolic biarylheptanoid and a flavonoid glycolsic product. If also present in leaves, these products could have a negative influence on the consumption of the aphid by the predator. Although B. brassicae preys were totally consumed, an adequate development of the predator was not observed, which allows to deduce that this aphid does not contain the necessary nutrients for the development of the predator and may also contains substances such as glucosinolates, which affect the predator survival. To confirm completely these hypotheses, physiological and morphological studies looking at the fatty corporal content of the predator and measuring the functional response with the different preys have to be done.

Fertility of E. connexa, fed with $M$. euphorbiae indicates that the reproductive phase began earlier in both the first and the second generation, at the age of 26 and 28 days, respectively (Figure 2). The first generation was that in which the reproduction stage was extended for more time, almost up to 100 days of age and together with the initial generation showed the highest fertility peaks.

Attention is drawn to the fact that the two laboratory generations (F2 and F3) of E. connexa were more precocious than those obtained from eggs deposited by fieldcollected adults (F1), starting oviposition almost 20 days earlier. This result can be attributed to the fact that the laboratory adults were fed during the whole cycle ad 


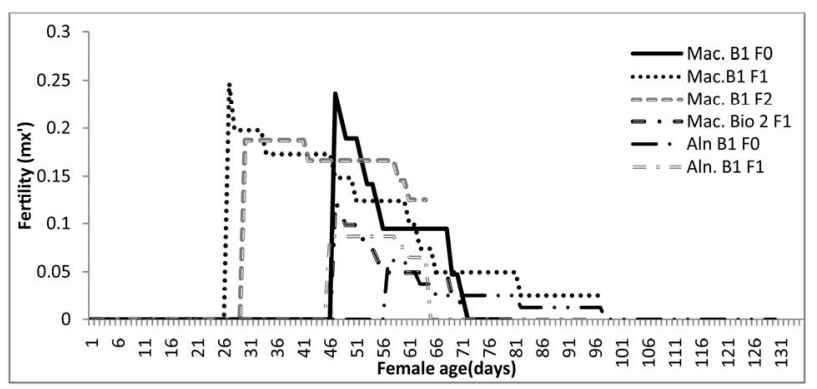

Figure 2. Fertility curves of Eriopis connexa fed with two aphid species during three generations. Mac. B1F0, generation derived from eggs laid by field collected adults supplied with Macrosiphum sp.; Mac. B1F1, first laboratory generation fed with Macrosiphum euphorbiae; Mac. B1F2, second laboratory generation supplied with M. euphorbiae; Aln. B1F0, generation derived from eggs laid by field collected adults supplied with the alder aphid. Aln. B1F1, first laboratory generation fed with the alder aphid. Mac. Bio 2F1, second bioassay with the first laboratory generation fed with M. euphorbiae.

libitum, while the field collected adults spent much energy in the process of searching for prey, and being generalists consume various species which may supply the insects demand but not permit the full expression of their reproductive potential.

Figure 2 shows that the predators' F1 generation, fed with alder aphids started their reproduction later (at age of 56 days) and obtained lower fertility peaks. This observation confirms that this prey species, despite being useful to maintain the rearing of the predator, is not an optimal food source since it does not contribute to the mass production of the insect. It could be only of use under special circumstances as food supplement during a particular rearing process of the predator.

Analyzing in a combined manner the survival curves and the fertility obtained with each food source provided to $E$. connexa (Figure 3), the results show that feeding $M$. euphorbiae during the three generations (Figures 3(A)(C)), produced the highest mortality occurred within the adult stage, once surpassed the age of maximum fertility, being this condition ideal for increasing in a quick manner the number of individuals of the rearing. This situation is more favorable during the predator's second generation where 29-d old females obtained their maximum fertility and the mortality curve accentuated from then on. For the initial and the first laboratory generations, as seen before, existed a mayor mortality tendency resembling a type I curve, but allowing an important proportion of individuals to reach the fertility peak before dying.

The results of the second bioassay arranged with $M$. euphorbiae exhibited a similar behavior; however it is more evident that when the survival decreases to a $40 \%$ the maximum fertility peaks have already been reached (Figure 3(D)).
An opposite situation occurred when the food was the alder aphid. Figures 3(E) and (F) indicate that the maximum fertility peaks are reached when the survival has already declined to almost the $20 \%$. This determines that the few individuals that achieve the adult stage may die before reaching the maximum fertility, an effect that reduces the population growth.

Demographic parameters: Table 3 summarizes the data found for these parameters. For the finite reproduction rate (Ro) or number of new females per female per generation, a statistically significant decrease is observed when passing from one generation to the other for the individuals of the predator fed with $M$. euphorbiae while the contrary occurred for those fed with the alder aphid.

Despite that other indicators have manifested that the alder aphid is not an optimum food for rearing of $E$. connexa, it is interesting to find that the maximum intrinsic growth rate $\left(\mathrm{r}_{\mathrm{m}}\right)$ or number of new females or individuals per female per day for the first generation predators, occurred when this prey was consumed. Likewise, negative $r_{m}$ values were obtained for the second generation of the coccinellid fed with Macrosiphum and for generation cero, supplied with the alder aphid.

The generational time $(\mathrm{T})$ or time that takes for a female from the start of the egg stage up to the first oviposition, a significantly longer time was noticed for the predators nourished with the alder aphid, time that almost decreased to half by those insects in the second generation when fed $M$. euphorbiae.

The intrinsic growth rate was found to be significantly higher for the second generation of the predator fed with the alder aphid, while between the other treatments, the observed differences were not significant, existing coherence between the intrinsic growth rate's value.

It can be concluded that the demographic parameters are definitively influenced by the food source, even though considered natural, produced differences within the growth potential that a population of $E$. connexa can display when supplied with different nutritional sources. In this regard the demographic parameters that could be calculated when using aphids as food source showed that the values found for the net intrinsic reproduction rate exhibit ample differences and are drastically inferior than those determined in previous research where the predator was supplied with other naturally occurring aphid Myzus persicae (Sulzer) [1]. The previous found intrinsic growth rate [1] is only similar to that observed for the second generation fed with Macrosiphum, while the generation time doubled for the initial and the first generation for the $M$. euphorbiae diet, with minor variations over the finite growth rate. These findings confirm the influence of the food provided to the larval instars, the ambient conditions and, particularly the prey species on the expression of the potential growth of the population. 

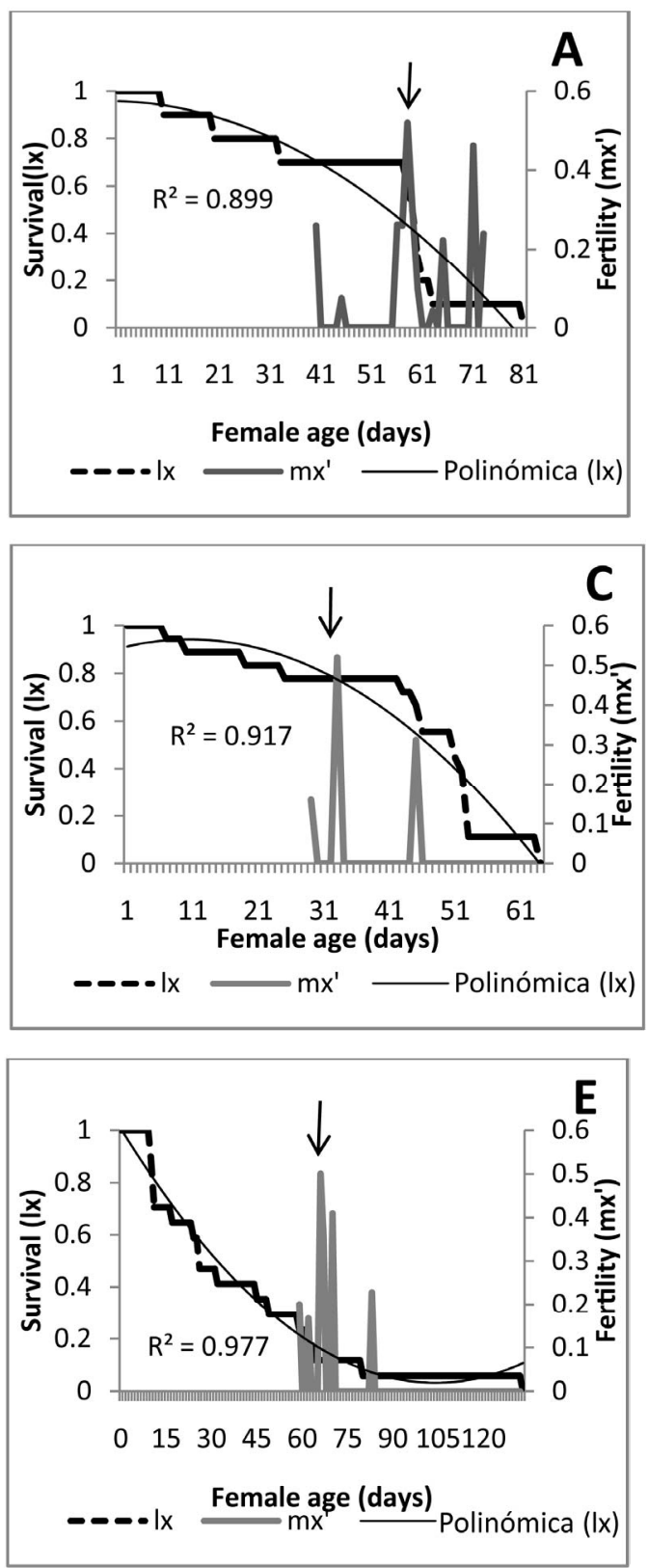
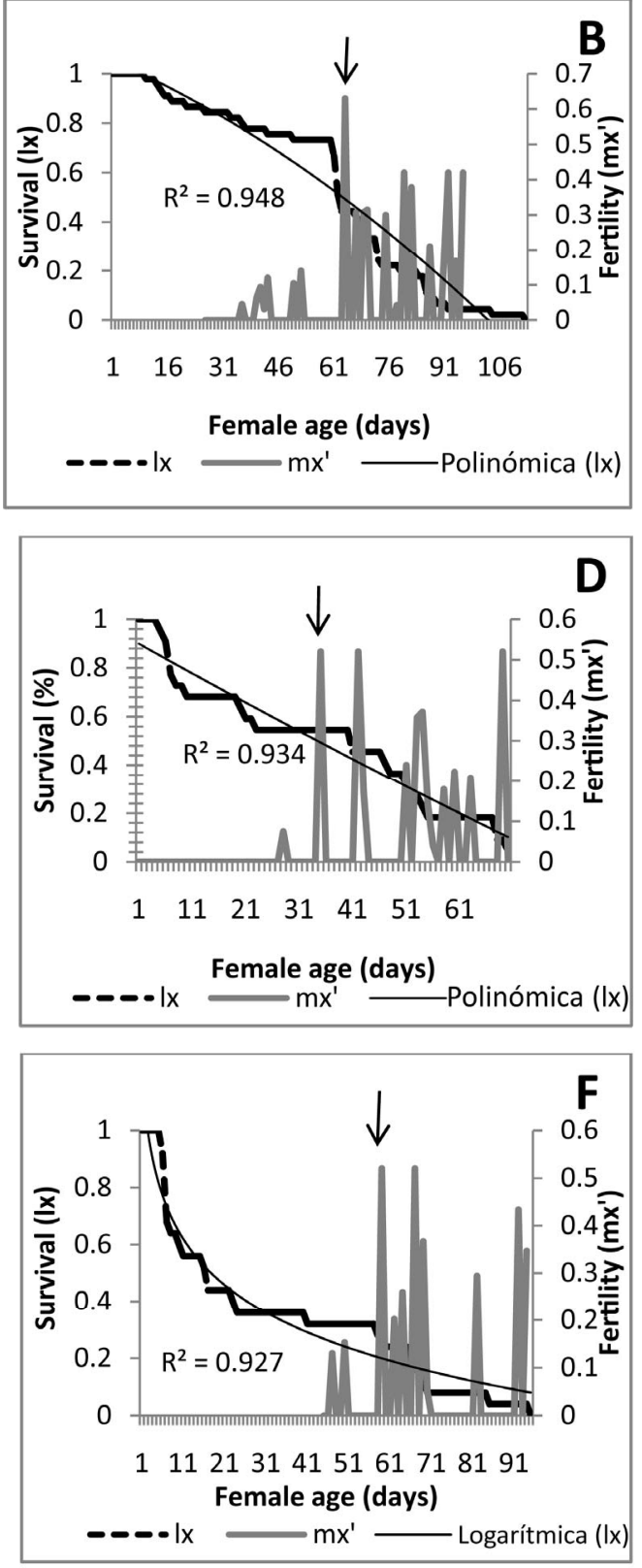

Figure 3. Survival curves and fertility of Eriopis connexa supplied with natural food sources: (A)-(C) with individuals of Macrosiphum euphorbiae in generations F0, F1 and F2, respectively; (D) second bioassay with generation F1 fed with M. euphorbiae; (E) and (F) generations F0 y F1 nourished with Pterocallis sp., collected from Alnus acuminata.

Table 3. Demographic parameters of Eriopis connexa determined with two natural food sources, several generations and laboratory bioassays.

\begin{tabular}{cccccc}
\hline Prey insect & Predator Generat. & Ro & $\mathbf{r}_{\mathbf{m}}$ & $\mathbf{T}$ & $\lambda$ \\
\hline Macrosiphum & 0 & $1.176 \pm 0.08 \mathrm{a}$ & $0.003 \pm 0.001 \mathrm{a}$ & $60.097 \pm 3.902 \mathrm{ab}$ & $1.003 \pm 0.001 \mathrm{a}$ \\
euphorbiae & 1 & $1.5 \pm 0.395 \mathrm{ab}$ & $0.007 \pm 0.005 \mathrm{ab}$ & $59.526 \pm 6.69 \mathrm{ab}$ & $1.007 \pm 0.005 \mathrm{ab}$ \\
& 2 & $0.792 \pm 0.515 \mathrm{a}$ & $-0.006 \pm 0.021 \mathrm{a}$ & $35.87 \pm 5.773 \mathrm{~b}$ & $0.999 \pm 0.021 \mathrm{a}$ \\
Pterocallis sp. & 0 & $0.591 \pm 0.224 \mathrm{a}$ & $-0.007 \pm 0.006 \mathrm{a}$ & $70.92 \pm 0.948 \mathrm{c}$ & $0.994 \pm 0.006 \mathrm{a}$ \\
& 1 & $1.789 \pm 0.0 \mathrm{~b}$ & $0.009 \pm 0.0 \mathrm{~b}$ & $62.879 \pm 0.0 \mathrm{ac}$ & $1.009 \pm 0.0 \mathrm{~b}$ \\
\hline
\end{tabular}

Ro finite reproduction rate; intrinsic growth rate $\mathrm{r}_{\mathrm{m}}$; generational time $\mathrm{T}$; net reproduction rate $\lambda$. Values of the same column followed by the same letter are not statistically different (Duncan $5 \%$ ) for each of the generations. 


\section{ACKNOWLEDGEMENTS}

We thank the "Universidad de Ciencias Aplicadas y Ambientales U.D.C.A" for the support received through the "Vicerrectoría de Investigaciones" and the financing by the universities research fund. Thanks to Ronald Simbaqueba for the determination of the Alder aphid. In addition we thank the students Victor Manuel Díaz, Alejandra Herrera; Jonathan Guerrero; Jonathan Burgos, members of the "Semillero de investigación Entomi dedicati"; the student Edson Urrego, young researcher U.D.C.A for their logistic help.

\section{REFERENCES}

[1] Duarte, H.W. and Zenner de Polanía, I. (2009) Tabla de vida del depredador Eriopis connexa connexa (Germar) (Coleoptera: Coccinellidae) Revista U.D.CA Actualidad \& Divulgación Científica, 12, 147-156.

[2] López-Ávila, A. and Espitia-Malagón, E. (2000) Plagas y benéficos en el cultivo de la papa en Colombia. MIP, Corpoica-PRONATTA.

[3] Ohashi, D.V. and Urdampilleta, J.D. (2003) Interacción entre insectos perjudiciales y benéficos en el cultivo del tabaco de Misiones, Argentina. Revista Investigación Agrícola, 32, 113-124.

[4] Rocha de Moraes, R., Lek, A.E. and Belarmino, E.C. (1991) Inimigos naturais de Rachiplusia nu (Guenée, 1852) e Pseudoplusia includens (Walter, 1857) (Lepidoptera: Noctuidae). Pesquisa Agropecuária Brasileira, 26, 57-64.

[5] Arias de Lavalle, G. and Costamagna, A.C. (1994) Study on the intake capacity of different instars of Eriopis connexa Germ. supplied with Alabama argillacea L. (Huebner) eggs. Summaries of the Biological Control Symposium, Granados.

[6] Doutt, R.L. (1968) El desarrollo histórico del Control Biológico. In: De Bach, P., Ed., Control Biológico de las Plagas de Insectos y Malas Hierbas, Compañía Editores Contreras, S.A. México.

[7] Bonte, M. and de Clercq, P. (2008) Developmental and reproductive fitness of Orius laevigatus (Hemiptera: Anthocoridae) reared on factitious and artificial diets. Journal of Economic Entomology, 101, 1127-1133. doi:10.1603/0022-0493(2008)101[1127:DARFOO]2.0.C $\underline{\mathrm{O} ; 2}$

[8] Khan, M.R. (2002) Mass rearing of Menochilus sexmaculatus Fabricus (Coleoptera: Coccinellidae) on natural and artificial diets. International Journal of Agriculture and Biology, 4, 107-109.

[9] Martos, A. and Niemeyer, H. (1990) Dos estudios sobre crianza masal del coccinélido Eriopis connexa Germar. Revista Peruana de Entomología, 32, 50-52.

[10] Venkatesan, T., Singh, S.P. and Jalali, S.K. (2001) Development of Cryptolaemus montrouzieri Mulsant (Coleoptera: Coccinellidae), a predator of mealybugs on freezedried artificial diet. Journal of Biological Control, 15, 139-142.

[11] Gyenge, J.A., Edelstein, J.D. and Salto, C.E. (1998) Efectos de la temperatura y la dieta en la biología de Eriopis connexa (Germar) (Coleoptera: Coccinellidae). Anais da Sociedade Entomológica do Brasil, 27, 345-346. doi:10.1590/S0301-80591998000300004

[12] Silva, R.B., Zanuncio, J,C., Serrão, J.E., Lima, E.R., Figueiredo, M.L.C. and Cruz, I. (2009) Suitability of different artificial diets for development and survival of stages of the predaceous ladybird beetle Eriopis connexa. Phytoparasitica, 37, 115-123. doi:10.1007/s12600-008-0015-2

[13] Maia, H.N.M., Luiz, A.J.B. and Campanhola, C. (2000) Statistical inference on associated fertility life table parameters using jackknife technique: Computational aspects. Journal of Economic Entomology, 93, 511-518. doi:10.1603/0022-0493-93.2.511

[14] Deevey, E.S. (1947) Life table for natural populations of animals. The Quarterly Review of Biology, 22, 283-314. doi: $10.1086 / 395888$

[15] Kushad, M.M., Brown, A.F., Kurilich, A.C., Juvik, J.A., Klein, B.P., Wallig, M.A. and Jeffery, E.H. (1999) Variation of glucosinolates in vegetable crops of Brassica oleracea. Journal of Agricultural and Food Chemistry, 47, 1541-1548. doi:10.1021/jf980985s

[16] Francis, F., Haubruge, E. and Gaspar, C. (2000) Influence of host plants on specialist/generalist aphids and development of Adalia bipuctanta (Coleoptera: Coccinellidae). European Journal of Entomology, 97,481-485.

[17] Hopkins, R.J., van Dam, N.M., Joop, J.A. and van Loon, J.J.A. (2009) Role of glucosinolates in insect-plant relationships and multitrophic interactions. Annual Review of Entomology, 54, 57-83. doi:10.1146/annurev.ento.54.110807.090623

[18] Kanzana, E., Pope,T.W., Tibbles, L., Bridges,M., Pickett, J.A., Bones, A.M., Powell, G. and Rossiter, J.T. (2007) The cabbage aphid: A walking mustard oil bomb. Proceeding of the Royal Society B Biological Sciences, 274, 2271-2277. doi:10.1098/rspb.2007.0237

[19] Stathas, G.J., Kontodimas, D.C., Karamaouna, F. and Kampouris, S. (2011) Thermal requirements and effect of temperature and prey on the development of the predator Harmonia axyridis. Environmental Entomology, 40, 15411545. doi: $10.1603 / \mathrm{EN} 10240$

[20] Reznik, S.Y. (2010) On the effects of diet and photoperiod on Harmonia axyridis (Pallas) (Coleoptera, Coccinellidae) larval development. Entomological Review, 90, 411-414. doi:10.1134/S0013873810040019

[21] Obrycki, J.J. and Orr, C.J. (1990) Suitability of three prey species for Nearctic populations of Coccinella septempunctata, Hippodamia variegata and Propylea quatuordecimpunctata (Coleoptera: Coccinellidae). Journal of Economic Entomology, 83, 1292-1297.

[22] González, J., Suárez, M., de Granoa, E. and Orozcode A.M. (1988) Constituyentes antifungicos en nódulos radicales de Alnus acuminata H.B.K. Agronomía Colombiana, 5, 83-85. 